\title{
SOAR LIKE GEESE:
}

\section{Building Developmental Network Relationships for Scholarship}

\author{
Maxine Adegbola, PhD, RN[Assistant professor] \\ University of Texas at Arlington College of Nursing
}

\begin{abstract}
Have you ever wished you knew someone who could help propel your career, or new idea, to the next level? Who could support your next grant initiative or otherwise direct you toward your professional goals? Most of your moments of wakefulness are preoccupied with thoughts such as, "If I could meet only a seasoned researcher who is an expert in pain genetics, then by association and osmosis I would excel beyond expectations!" •Well, wishes are unfilled dreams. If you can dream it, you can make it happen, with strategic networking and scholarly tailgating. The major ingredients in actualizing dreams are getting started and responsibly taking charge. Robert Louis Stevenson wrote, "Don't judge each day by the harvest you reap, but by the seeds you plant." Incrementally planting relational seeds will foster a harvest of relationships that can propel you to the realization of your professional dreams.
\end{abstract}

\section{Scholarly Tailgating}

Like geese, people who share a common direction or relationship can get where they are going quicker and easier than those who try to go it alone. Geese migrate in $\mathrm{V}$ formation. As each bird flaps its wings, uplift is created for the birds that follow. This formation adds at least 70 percent more flying range than if each bird flew alone (Lissaman \& Schollenberger, 1970).

Benefiting from another scholar's uplift is scholarly tailgating, the process of networking to create an aerodynamic lift for one's career and capitalizing on the expertise of others to help professional dreams materialize. Realized dreams for nurses and other scholars are established by creating relationships where individuals bond, share common characteristics, beliefs, and values (Higgins, Chandler, \& Kram, 2007), wherein "birds of a feather flock together," network, and benefit from each other's aerodynamic uplift.

My purpose in writing this article is to inspire and motivate doctoral students and graduates to include networking in their repertoire of professional relational skill sets. Throughout this discussion, I use the terms developmental networks for developmental relationships and connectors for developers interchangeably to represent social networking interactions at work.

\section{Practical Suggestions}

The lived experience of the doctoral nursing student who yearns for mentors and professional identity development has been reported in the literature (Heinrich, 2005). To

Contact Dr. Adegbola at adegbola@uta.edu.

She introduced the concepts and terms presented in this article at a presentation titled "Networking: Building Relationships" at the doctoral students' luncheon at the College of Nursing in October 2008. 
achieve continued success, it becomes necessary for doctoral students to develop diverse network relationships.

Networking must begin the moment there is a need or desire. An old proverb states that when the student is ready, a teacher appears. The yearning, expectant student must actively pursue the desire.

My pursuit was activated during the early period of my doctoral education. Our professors encouraged our cohort of doctoral students to participate in a regional research conference offered by Southern Nursing Research Society. After I committed to attend the conference, my goal was to meet at least three individuals who could become springboards for my professional and research endeavors. That was the beginning of a conscious awareness of professional development networking.

I updated my business cards to include doctoral student status and my research interests and took cards with me to distribute at the conference. I worked the conference floors, interacting and sharing research interests and contact information. I returned from the conference with multiple business cards and three major leads to researchers in my area of interest. Within two days of returning from the conference, I sent emails to my new friends, thanking them for sharing their expertise and offering to share my expertise with them. For those who requested bibliographies and other information, I sent those items promptly. This response reminded my new colleagues of our meeting and led to the exchange of a mail distribution list. On the back of received business cards, I put the date, type of meeting, and other relevant comments prior to filing the cards in a folder.

Over the years, I have maintained ties with these seasoned researchers. The strength of the ties has varied relative to the closeness of the relationship or need at the time. I constantly use electronic media to maintain contact and transcend the barriers of distance and time; it is easier and economically prudent to keep in contact this way. I find that the early morning is the best time to send emails, before the rest of the world is awake. When using the telephone to contact network partners, one must be mindful of hemispheric time zones.

The importance of networking became evident when my dissertation plans and selected research site did not materialize. My database of developers in my research area became the catalyst for successfully recruiting subjects for the research study. Having maintained both strong and weak ties with individuals from the first research conference I attended, I was able to successfully revisit my dissertation plans with these contacts. Simply, the strategic networking and developmental relationships I nurtured proved beneficial during this and other critical times of need. The Sidebar offers suggestions for networking when your needs require action that can best be described as scholarly tailgating.

\section{Theoretical Framework}

The theoretical underpinning of developmental network relationships and scholarly tailgating is based on social network theory. Kram's (1985) early work described mentoring as a constellation of relationships, wherein individuals rely not just on one, but multiple individuals for developmental support during their career. Beyond mentoring, networking results in developmental relationships that support, strengthen, and enhance career mobility (Higgins \& Kram, 2001).

\section{SOCIAL NETWORKS/DEVELOPMENTAL NETWORKS}

Social networks are beneficial for doctoral scholars who must be prepared to respond innovatively to global health issues (Aday, 2001; Ketefian, Davidson, Daly, Chang, \& 
Srisuphan, 2005; Ketefian \& Redman, 1997) and take the initiative to use their experiences in areas beyond the institutional walls of academia. Social networks are conglomerates of dynamic relational entanglements and webs in which people or entities are connected and engaged in multiple roles with "multiplexity of ties" between them (Quatman \& Chelladurai, 2008, p. 347). Networking is a strategically designed process of building relationships and sharing information and services among individuals with common interests. Byproducts of networking are relationship development, increased visibility, and career advancement.

\section{DOCTORAL EDUCATION/NETWORKING}

Doctoral students desire to network professionally, build relationships that are helpful in scholarly identity (Heinrich, 2005), get expert input into their research trajectory, and receive capital for professional marketing strategies (Perlmutter \& Porter, 2005). In Heinrich's 2005 study, doctoral students or new doctorates were eager to have expertise and direction from mentors, but, at times, mentors were few and unavailable.

Doctoral students should learn to develop professional relationships that help shape their scholastic achievements. Having a variety of professional and multidisciplinary relationships enhances the doctoral student's ability to develop sound professional identity, enables social role modeling (Trocchia \& Berkowitz, 1999), and prevents blighted professional role development (Sweitzer, 2007, 2008).

It is imperative for doctoral students to develop professional relationships outside of mentored dyads. To benefit from professional development from a variety of sources, doctoral students must take control and pave their own professional course, actively and strategically networking to craft and develop their professional identities, connections, and relationships (Heinrich, 2005). Walker and colleagues (2008) describe this type of initiative as synthesis of scholarship, wherein the formative process includes both technical training and professional growth of the learner who is seeking development. It is essential to soar to scholarly heights with others who have similar directional goals for success.

\section{Conclusion}

Strategic developmental networking should start now. You may never again have the opportunities you have now to network with colleagues and build invaluable relationships that, if managed correctly, can assist in your professional growth. Each day, plant seeds in your network relationships. The rewards you reap will exponentially increase the harvest of benefits. The key is to plant seeds and take deliberate actions each day.

Always have your business cards or other take-away contact information in your hand or pocket. Once you have established networks, it is essential to cherish and balance the ranges of ties, including weak as well as strong ties, in your reciprocal relationship circle. These network relationships should include developers from various social systems such as peers, community developers, and those inside and outside the organization.

Strategic planning is necessary to establish and maintain developmental relationships. As you build relationships in your area of influence, a worthwhile lesson can be learned from geese. While flying with your fellows, honk and encourage others to soar with you! Network relationships can propel scholars, provide aerodynamic lift, and enable scholarly tailgating. Soar to the heights of your scholarly dreams! 


\section{References}

Aday, LA. At risk in America: The health and health care needs of vulnerable populations in the United States. San Francisco: Jossey-Bass; 2001.

Heinrich KT. Halfway between receiving and giving: A relational analysis of doctorate-prepared nurse-scholars' first 5 years after graduation. Journal of Professional Nursing. 2005; 21(5):303-313. [PubMed: 16179243]

Higgins, M.; Chandler, D.; Kram, K. Developmental initiation and developmental networks. In: Ragins, R.; Kram, K., editors. The handbook of mentoring at work: Theory, research and practice. Thousand Oaks, CA: Sage; 2007. p. 349-372.

Higgins M, Kram K. Reconceptualizing mentoring at work: A developmental network perspective. Academy of Management Review. 2001; 26(2):264-266.

Ketefian S, Davidson P, Daly J, Chang E, Srisuphan W. Issues and challenges in international doctoral education in nursing. Nursing \& Health Sciences. 2005; 7(3):150-156. [PubMed: 16083477]

Ketefian S, Redman RW. Nursing science in the global community. Image: Journal of Nursing Scholarship. 1997; 29(1):11-15.

Kram, K. Mentoring at work: Developmental relationships in organizational life. Glenview, IL: Scott Foresman; 1985.

Lissaman PBS, Schollenberger CA. Formation flight of birds. Science. 1970; 168(3934):1003-1005. [PubMed: 5441020]

Perlmutter D, Porter L. Thinking beyond the dissertation. Chronicle of Higher Education. 2005; 52(17):C1-C4.

Quatman C, Chelladurai P. Social network theory and analysis: A complementary lens for inquiry. Journal of Sport Management. 2008; 22(3):338-360.

Sweitzer VL. Professional identity development among business doctoral students: A social networks perspective (abstract). ProQuest Information \& Learning). Dissertation Abstracts International Section A: Humanities and Social Sciences. 2007; 68(5):1849.

Sweitzer VL. Networking to develop a professional identity: A look at the first-semester experience of doctoral students in business. New Directions for Teaching \& Learning. 2008; (113):4356.10.1002/t1.307

Trocchia PJ, Berkowitz D. Getting doctored: A proposed model of marketing doctoral student socialization. European Journal of Marketing. 1999; 33(7):746-760.

Walker, GE.; Golde, CM.; Jones, L.; Conklin Bueschel, A.; Hutchings, P. The formation of scholars: Rethinking doctoral education for the twenty-first century. San Francisco: Jossey-Bass; 2008. 


\section{Sidebar}

Networking Strategies and Suggestions

\section{Purpose of building networking relationships}

- Foster relationship building with other professionals

- Enhance survival in academia and practice

- Activate desire to help others with their career path

- Propel professional identity

- Establish global partnerships

- Forge collegial and collaborative relationships to tackle and solve global issues and problems

\section{Helpful tips for networking}

- Capitalize on all opportunities to network.

- Maintain a desire to meet others. Seek, pursue new territories and collaborative relationships.

- In delicate situations, use a frame such as, "If I can be of assistance in the future, call me. Here is my contact information."

- Move away from groups already known to you. Meet others from other departments or disciplines.

- Establish business card exchanges and follow up to maintain ties.

- Build electronic networks of contacts.

- Speak up at meetings or public forums.

- Write/submit manuscripts for publication.

- Tell mentors about your interests and networking needs.

- When you do not know anyone else in the circle, introduce yourself and think of appropriate ice breakers.

- When you would like to meet a colleague, email or call the individual and selfintroduce. Discuss common interests and let the leader know of your interests.

- Prior to attending a conference, request a meeting with speakers whose work is of interest to you.

- Suggest meeting your developer for lunch or refreshments and offer to pay. 